\title{
Causality Relationship between Trading Volume and Stock Return: Evidence from Nepalese Stock Market
}

\author{
Shivaram Shrestha'
}

\begin{abstract}
This paper aims to empirically examine the causal relation between trading volume and stock returns for Nepalese Stock Market using Garner causality procedure, using monthly data for the period of July 2007 to February 2015. The study analyzed for the investigation of the Granger causality between trading volume and stock price using monthly data sets to ascertain if the causality runs from volume to stock price or from stock price to volume or in both directions. This study detected unidirectional causality from stock returns to trading volume that is indicative of noise trading model of return volume interaction in this market.
\end{abstract}

Key Words: Trading volume, Stock returns, Granger causality test, Nepalese stock market

\section{INTRODUCTION}

Return and volume are two important elements of every transaction and these elements are jointly determined by the same market dynamics and may contain valuable information about securities. Therefore, it is generally believed that these two variables should have very close and straightforward relationship. 'Volume analysis' is an important tool in the archery of technical analysts. It tries to forecast future price move on the basis of past volume. Two famous stock market adages say: "It takes volume to make prices move", and "Volume is heavy in bull market and light in bear market". These adages imply two different kinds of causalities between these two variables. However, conceptual and empirical findings on the relationship between these two variables are not so straightforward. Causality is a kind of statistical feedback concept which is widely used in the building of forecasting models. Causality tests can provide useful information on whether knowledge of past stock returns improves short run forecasts of current and

Mr. Shrestha is Ph.D. research scholar at the Faculty of Management, Tribhuvan University.

Email: shivaram.shrestha@gmail.com 
future trading volume. There are several evidence for the presence of a causal relation between stock returns and trading volume in the literatures. First, Epps (1975) gave evidence based on the asymmetric reaction of two groups of investors-bulls and bearsto the positive information and negative information. Secondly, Clark (1973) developed mixture of distribution model and provided evidence that the speed of information flow is a latent common factor which influence stock returns and trading volume simultaneously. Third evidence is the sequential arrival of information model of Copeland (1976) which indicated a positive relationship between price changes and trading volume.

The objective of this study is to empirically examine the causal relation between volume and share price for Nepalese Stock Market using Garnger causality procedure. The study investigate the Granger causality between stock returns and trading volumes to ascertain if the causality runs from volume to stock returns or from stock returns to volume or in both directions. The study uses monthly time series data sets. The rest of the paper is organized as follows: the next section discusses the conceptual relationship between volume and price and presents a brief survey of empirical research on this issue. The third section highlights the methodology of the present study. This is followed by discussions on the results of the study in the fourth section. Section 5 concludes the paper.

\section{REVIEW OF LITERATURE}

Granger (1969) developed a methodology to examine whether changes in one series cause changes in another. If the current value of $Y$ can be predicted by using the past values of $X$ and considering other relevant information including the past values of $\mathrm{Y}$, it may be concluded that $\mathrm{X}$ causes $\mathrm{Y}$. To determine the presence of and the direction of a causal relation between return and volume, the Granger causality method has been chosen. Granger causality method was utilized by several researchers to investigate the causal relation between share price and trading volume. Some examples of such studies are as follows. Most of studies found bidirectional causality between trading volume and stock returns volatility. Some of the studies found unidirectional causality from volume to volatility and some from volatility to volume.

In nutshell, on the basis of above-mentioned studies it can be stated that the significant efforts have been made at the international level to evaluate stock return and trading volume, whereas in Nepal, the causal relationship between stock price index and market capitalizations with macro economic variables has been investigated by G.C. and Neupane (2006) using the time series data for the year 1988 to 2005. The study found the empirical evidence that the direction of causality from real GDP to stock price index but no reverse causation from stock price index to real GDP. The study also concluded bidirectional causality between market capitalizations. The causal relationship between stock returns and trading volume has not been investigated in Nepalese stock market. Therefore, the current study is an attempt to fill this gap and sheds light on the informational efficiency of Nepalese stock market. This paper examines the causal 


\begin{tabular}{|c|c|c|c|}
\hline Author & Assets & Period & Causality \\
\hline Jain \& Joh (1988) & S\&P 500 stock index & 1/1979-12/1983 & unidirectional; Returns Volume \\
\hline $\begin{array}{l}\text { Hiemstra \& Jones } \\
\text { (1994) }\end{array}$ & DIJA index & $\begin{array}{l}\text { 1915- } \\
1940 ; 1941-1990\end{array}$ & Bidirectional; Returns Volume \\
\hline $\begin{array}{l}\text { Gwilym, McMillan and } \\
\text { Speight (1999) }\end{array}$ & LIFFE future contract & 1/1995-6/1995 & Bidirectional; Returns Volume \\
\hline $\begin{array}{l}\text { Chen, Firth and Rui } \\
\text { (2001) }\end{array}$ & $\begin{array}{l}\text { Nine developed national } \\
\text { Market }\end{array}$ & $1973-2000$ & unidirectional; Returns Volume \\
\hline Ciner (2002) & $\begin{array}{l}\text { Tokyo Commodity } \\
\text { Exchange }\end{array}$ & $1 / 1992-9 / 2000$ & Bidirectional; Returns Volume \\
\hline Luu and Martens (2003) & S\&P 500 Index & 1/1990-6/1999 & $\begin{array}{l}\text { INTRA: Bidirectional; Returns } \\
\text { Volume SQUARED RETURNS: } \\
\text { unidirectional; Returns Volume }\end{array}$ \\
\hline Sarwar (2003) & $\begin{array}{l}\text { Currency options on the } \\
\text { British Pound }\end{array}$ & $1-1993-10 / 1995$ & Bidirectional; Returns Volume \\
\hline $\begin{array}{l}\text { Darrat, Rahman and } \\
\text { Zhong (2003) }\end{array}$ & DJIA Stocks & 4/1998-6/1998 & Bidirectional; Returns Volume \\
\hline Chen (2007) & $\begin{array}{l}\text { Live cattle, pork bellies, } \\
\text { German mark and Swiss } \\
\text { franc futures }\end{array}$ & 1/1995-12/1995 & Bidirectional; Returns Volume \\
\hline Hatrick et al. (2011) & HSBC stock & $\begin{array}{l}01 / 2009- \\
05 / 2009\end{array}$ & Bidirectional; Returns Volume \\
\hline Hussain (2011) & DAX 30 Index & $5 / 2004-9 / 2005$ & $\begin{array}{l}\text { unidirectional; Volume Returns } \\
\text { but do NOT investigate returns } \\
\text { Volume }\end{array}$ \\
\hline $\begin{array}{l}\text { Attari, Rafiq and Awan } \\
\text { (2012) }\end{array}$ & Karachi Stock Exchange & $2000-2012$ & Bidirectional; Return Volume \\
\hline Darwish (2012) & Palestine Stock Exchange & $10 / 2000-8 / 2010$ & Bidirectional; Return Volume \\
\hline Halova (2012) & $\begin{array}{l}\text { NYMEX (oil and gas } \\
\text { futures) }\end{array}$ & $\begin{array}{l}1 / 8 / 2008- \\
24 / 9 / 2010\end{array}$ & $\begin{array}{l}\text { Absolute return: Bidirectional; } \\
\text { returns Volume Conditional } \\
\text { variance: unidirectional; Returns } \\
\text { Volume }\end{array}$ \\
\hline $\begin{array}{l}\text { Abdullahi, Kouhy and } \\
\text { Muhammad (2014) }\end{array}$ & $\begin{array}{l}\text { West Texas Intermediates } \\
\text { and Brent crude oil futures }\end{array}$ & $1 / 2008-5 / 2011$ & $\begin{array}{l}\text { Neither trading volume nor } \\
\text { returns have the power to } \\
\text { predict the other }\end{array}$ \\
\hline $\begin{array}{l}\text { Samman and Al-Jafari } \\
\text { (2015) }\end{array}$ & Muscat securities market & $1 / 2009-12 / 2013$ & unidirectional; Volume Return \\
\hline
\end{tabular}

relationship between stock returns and trading volume context in Nepalese stock market and contributes to the literature in several respects. It deploys the Granger causality test to investigate information flow between the variables instead of ARIMA. Moreover, the time period considered in the study helps to evaluate the impact of new regime changes in political situation of Nepal. Thus, the study will enhance the understanding of market asymmetry, market efficiency and information processing in Nepalese stock market.

\section{DATA AND METHODOLOGY}

This section describes the following aspects of research methodology to test the relationship between stock returns and trading volume in Nepalese stock market: (i) 
nature and sources of data, (ii) selection of enterprises, (iii) the variables, (iv) methods of analysis, and (v) the limitations of the study.

\section{Nature and Sources of Data}

The relationship between trading volume and stock returns are examined by using secondary sources of trading volume and return data series. Most of the data related to stock returns and trading volume were collected from annual report and official reports of Security Exchange Board of Nepal (SEBON), official website of Nepalese Stock Exchange (NEPSE). The data set used in this study comprises monthly closing prices and trading volume in NEPSE. The study period covers the time period of eight years, ranging from July 2007 to February 2015 and thereby making 92 months. The monthly data set are collected from http://www.nepalstock.com/ which is available from July 2007 onward. Both series, (monthly trading volume and monthly closing prices) are expressed in the local currency. The monthly stock returns are computed using monthly closing prices.

\section{Selection of enterprises}

The study consists of all listed companies of Nepalese stock market at index level. The study also considers sector wise data of Nepalese stock market.

\section{Variables specification}

The study mainly considers monthly volume series and return series to examine the relationship between trading volume and stock returns.

Trading volume: The total number of shares traded were used to measure of trading volume for study of aggregate trading activities e.g., Epps and Epps, (1976), Gallant, Rossi, and Tauchen, (1992), Hiemstra and Jones (1994) and Ying (1966). Other studies used the total number of shares traded divided by the total number of shares outstanding as a measure of trading volume, e.g., Campbell, Grossman, Wang (1993), and LeBaron (1992). Individual share volume was often used in the analysis of price/volume and volatility/volume relations, e.g., Andersen (1996), Epps and Epps (1976), and Lamoureux and Lastrapes $(1990,1994)$. Alternatively, even the total number of trades was used by Conrad, Hameed, and Niden, (1994). James and Edmister, (1983) used the number of trading days per year as measures of trading activity.

The NEPSE provides three measures of trading volume: 1) the volume traded (the sum of the number of share traded during the period); 2) the number of trades (the sum of trade during the period); 3) the total value traded expressed in NPR (the sum of the price of share traded times the number of share traded). This study uses the total value traded of the shares as the measure of trading volume because it takes into account of the relative market value of shares while other measures mentioned above do not. The level volume series is non-stationary, thus the study use first order log difference volume series. The volume series at the time t noted as $\mathrm{D}\left(\mathrm{LOG}\left(\mathrm{V}_{\mathrm{t}}\right)\right)$ is expressed as: 
$\mathrm{D}\left(\right.$ LOG $\left.\left(\mathrm{V}_{\mathrm{t}}\right)\right)=$ First order log differences $\left(\right.$ Volume $\left._{\mathrm{t}}\right)$

Where Volume $_{t}$ is the NPR value of the shares traded at time $t$, and $D($.$) is the first$ order difference operator.

Stock returns: The study considered monthly price index change as stock returns. A monthly price index change is calculated using the natural log of the ratio of a stock's price index $(P)$ from the current month $(t)$ to the previous month (t-1) as:

$$
\mathrm{R}_{\mathrm{t}}=\text { monthly stock returns }=\operatorname{Ln}\left(\frac{\mathrm{P}_{\mathrm{t}}}{\mathrm{P}_{\mathrm{t}}}\right)
$$

Where, $\mathrm{P}_{\mathrm{t}}$ represents the closing price index for the period $\mathrm{t}$; $\mathrm{t}$ is the time in months. $P_{t-1}$ is the closing price index for the period of $t-1 ; \operatorname{Ln}($.$) is the natural logarithm operator.$ All returns are expressed in local currencies and are not adjusted for dividends.

\section{Methods of analysis}

As stated earlier, the objective of the paper is to determine existence of and the direction of causality between returns and volume on the NEPSE as per the conventions of the Granger Causality methodology(Granger, 1969). To measure causality between the stock returns and trading volume, the Granger Causality Model is used. This test is used to determine whether or not return is the cause of trading volume, vice versa, or neither. The Granger Causality test provides four possible outcomes to a regression of stock returns and trading volume: No causality, stock returns causes trading volume only, trading volume causes stock returns only, and bi-directional causality. The Granger Causality Test estimates the results of two regressions:

$$
\begin{aligned}
& \mathrm{R}_{\mathrm{t}}=\mu_{\mathrm{R}}+\sum_{\mathrm{t}=1}^{\rho} \alpha_{\mathrm{j}} \cdot \mathrm{R}_{\mathrm{t}-1}+\sum_{\mathrm{t}=1}^{\rho} \beta_{\mathrm{j}} \cdot \mathrm{V}_{\mathrm{t}-1}+\varepsilon_{\mathrm{t}} \\
& \mathrm{V}_{\mathrm{t}}=\mu_{\mathrm{V}}+\sum_{\mathrm{t}=1}^{\rho} \alpha_{\mathrm{j}} \cdot \mathrm{V}_{\mathrm{t}-1}+\sum_{\mathrm{t}=1}^{\rho} \beta_{\mathrm{j}} \cdot \mathrm{R}_{\mathrm{t}-1}+\varepsilon_{\mathrm{t}}
\end{aligned}
$$

Where, $\quad R_{t}=$ monthly stock returns of NEPSE index.

$\mathrm{V}_{\mathrm{t}}=$ monthly trading volume of NEPSE.

Equation (1) regresses the dependent variable, $R_{t}$, to how it related to lagged variables of $R_{t}$ and $V_{t}$. Equation (2) is similar to Equation (1), it regresses to lagged variables of $R_{t}$ and $V_{t}$. Both equations assume that the disturbance terms, $\varepsilon_{t}$, are uncorrelated. The null hypothesis for equation (1) and (2) state no evidence of causation from $R_{t}$ to $V_{t}$ respectively.

\section{Unit root Test}

Unit root test has a crucial importance in the time series analysis as the choice of the techniques and procedures for further analysis and modeling of series depends on their order of integration. Without taking into account the presence of unit root in 
the variables, the analysis may produce spurious results. For this purpose, the study uses the well-known Dickey-Fuller or the Augmented Dickey-Fuller (ADF) test (Dickey and Fuller, 1981) and Phillips- Perron (PP) unit roots are employed. Two variants of this model are estimated: (i) including only a constant term $(\alpha)$ as the deterministic regressor and (ii) including both constant $(\alpha)$ and time trend $(t)$ terms as deterministic regressors. $A D F$ unit root test is sensitive towards the lag length included in the regression equation. So, the lag lengths have been chosen based on Akaike Information Criterion (AIC). The respective models estimated took the following form:

$$
\begin{aligned}
& \Delta y_{t}=\alpha_{0}+\gamma y_{t-1}+\sum_{i=1}^{\rho} \beta_{i} \Delta y_{t-i}+\varepsilon_{t} \ldots \ldots \ldots . . . . \\
& \Delta y_{t}=\alpha_{0}+\gamma y_{t-1}+\alpha_{1} t+\sum_{i=1}^{\rho} \beta_{i} \Delta y_{t-i}+\varepsilon_{t}
\end{aligned}
$$

Where, $y$ is the stock returns or trading volume.

\section{Johansen's Co-integration Test}

After confirming the non-stationary of time series in their levels, the next step is the investigation of presence of co-integration between trading volume and stock returns. For this purpose, the study employed Johansen's multivariate maximum likelihood method using this co-integrated process to test those variables have existed long-run equilibrium relationship (Johansen 1988). Co-integration test is to identify existence of any co-integrating relationship between trading volume and stock returns in Nepalese stock market.

Johansen's approach has used $\pi$ to distinguish the number of co-integrated vector. It could use two likelihood ratio tests to process co-integration.

a. Likelihood ratio or Trace Test:

$\mathrm{H}_{0}$ : Rank $(\pi)<\mathrm{r}$ (at most $\mathrm{r}$ integrated vector)

$H_{1}$ : Rank $(\pi)>r$ (at least $r+1$ integrated vector)

$$
\lambda_{\text {trace }}=-T \sum_{i=r+1}^{n} \ln \left(1-\lambda_{i}\right)
$$

T is sample size, $\lambda_{i}$ is estimate of characteristic root. If test rejects $H_{0}$ that means variables exist at least $r+1$ (i.e. long-term co-integrated relationship).

b. Maximum Eigenvalue Test:

The maximum eigenvalue of statistic $\left(\lambda_{\max }\right)$ tests the null hypothesis of co-integrating vectors against the alternative of $r+1$ co-integrating vectors.

$\mathrm{H}_{0}$ : Rank $(\pi) \mathrm{r}$ (at most $\mathrm{r}$ integrated vector)

$\mathrm{H}_{1}$ : Rank $(\pi)>\mathrm{r}$ (at least $\mathrm{r}+1$ integrated vector)

$$
\lambda_{\max }(r, r+1)=-T\left(1-\lambda_{r+1}\right)
$$

If test accept $\mathrm{H}_{0}$ that means variables have $r$ co-integrated vector. 


\section{Limitations of the study}

There are a large number of non-listed companies contributing to the dynamics of Nepalese economy; these are not included in the study due to data problems. The study used monthly data ranging from July 2007 to February 2015 comprising 92 months period. Perhaps a longer period of data could have yielded a more refined result. The results relating to causal relationship between stock returns and trading volume in this study based on Granger causality test using available monthly stock returns and trading volume data series.

\section{ESTIMATION AND RESULTS}

The purpose of this section is to provide the empirical results of Granger causality between stock returns and trading volume in Nepalese stock market. The analysis consist of: (i) descriptive statistics of variables, (ii) Unit root test, (iii) Johansen's co-integration test and (iv) Results of Granger causality between stock returns and trading volume.

\section{Descriptive statistics}

The study started investigation with same basic descriptive statistics of time series of stock returns and trading volume from monthly data of NEPSE index for the period of 2007.07 to 2015.02 . It would provide insight to the average size and deviation from mean value of the variable. The descriptive statistics for the variables are shown in annex 1 . The analysis shows that the mean value of monthly stock returns over the period is -0.0039 with standard deviation of 0.3313 . The maximum and minimum returns observed are 1.3438 and -1.4224 respectively. Applying Jarque-Bera test for normality, the test statistics clearly rejects the hypothesis, which implies that pattern of monthly trading volume and monthly stock stock returns series does not conform to normal distribution, which is the precondition for any market to be efficient in the weak form (Fama (1965), Stevenson and Bear (1970), Reddy (1997), Kamath (2008) and Mahajan and Singh (2008). Further, skewness and excess kurtosis preserve the evidence of the nature of departure from normality because the skewness and kurtosis value of stock returns are -0.3949 and 13.8980 respectively. The skewness coefficient in excess of unity is generally taken to be fairly extreme. Kurtosis generally either much higher or lower indicates extreme leptokurtic or extreme platykurtic (Parkinson, 1980). Thus, monthly stock returns and trading volume series are not normally distributed.

Similarly, the descriptive statistics of sector wise data set shows that the highest mean value of return series is $2.316 \%$ with standard deviation of $7.723 \%$ was found in hotel sector among the sectors. The highest mean value of trading volume is NPR 1654.896 with standard deviation of 3069.45 in commercial bank sector. The monthly stock returns and trading volume series are not normally distributed in all sectors except return series of commercial bank and other sector. It implies that pattern of almost all variables does not conform to normal distribution. 


\section{Unit Root Test}

The time series variables - stock returns and trading volume - should be stationary for the analysis of time series statistics. The unit root test helps to test whether the times series variables are stationary or not.

The unit root test results are shown in annex 2. The statistics are inferior to the McKinnon critical value at $10 \%$ level. This indicates that the null hypothesis of unit root is rejected for the stock returns and volume variable have unit root in level form and no unit root in log differenced trading volume series in ADF test.

The PP test also rejected the null hypothesis of unit root for stock return and log differenced trading volume variable as of ADF test. Philips-Perron test have shown that volume variable have unit root in level forms and no unit root in the first difference. Hence, the study comes to conclusion that trading volume times series variable of the study should be changed with first order difference to get these variables are stationary. Having determined the non-stationary of time series in their levels, and they are also of some order of integration I(1), co-integration test has been applied to ascertain whether trading volume and stock returns are co-integrated or not. The similar result for sector wise data of stock returns and log differenced trading volume.

\section{Johansen's Co-integration Test}

Johansen's co-integration is an econometric property of time series variables. If two or more series are themselves non stationary, but a linear combination of time is stationary, then the series are said to be co-integrated. A vector of time series variable is co-integrated if each element of order one, I (1), but there exists a nonzero vector (called co-integrating vector) such that is integrated of order zero, I (0). Economic theory often suggests that certain subset of variable should be linked by a long-run equilibrium relationship. The Johansen's co-integration tests statistics are shown in annex 3 . The result of the Johansen's co-integration tests shows that the null hypothesis of no cointegration between trading volume and stock returns is rejected since both Trace and Max-Eigen statistics are larger than the critical values at 1 percent significance level. In other words, for co-integrating regression, trading volume $=f$ (stock returns), one can reject the null hypothesis $r=0$ against the alternative hypothesis $r=1$ since both Trace and Max-Eigen statistics are larger than the critical values at 1 percent significance level but cannot reject the null $r 1$ against the alternative $r=2$ since both Trace and MaxEigen statistics are less than the critical values even at 1 percent level. The fact that the presence of co-integration between trading volume and stock returns suggest (i) that there is a long-run equilibrium relationship between the two time series, and (ii) the existence of causality in at least one direction.

\section{Granger casualty test}

The procedure used in this study for testing statistical causality relationship between stock returns and trading volume is the 'Granger-causality' test, developed by 
C.W.J. Granger in 1969. The aim of this test is to determine the predictive content of one variable beyond that inherent in the explanatory variable itself. The Granger causality test requires the variables in the test to be stationary. According to the Granger representation theorem, if two variables say, $X_{t}$ and $Y_{t}$ are co integrated and each is individually $I(1)$, that is, integrated of order 1 , then either $X_{t}$ must Granger-cause $Y_{t}$ or $Y_{t}$ must Granger-cause $\mathrm{X}_{\mathrm{t}}$.

The results of Granger causality tests between trading volume, stock returns and between trading volume and return volatility are shown in annex 4 . The analyses indicate that the null hypothesis that stock returns do not Granger cause volume could not be rejected for market data series from 2007.07 to 2015.02. The F-statistic test shows the test is significant at $10 \%$ level. Therefore, there is a unidirectional Granger causality running from stock returns to trading volume but not vice versa. This means that volume does not contain predictive power for the stock returns and directional change in stock returns. The results of the Granger causality test in the sector wise firms also shows similar findings. The commercial bank sector shows two-way Granger causality between stock returns and trading volume. Finance company shows one way Granger causality from trading volume to stock returns. Manufacturing and processing sector shows one way Granger causality from stock returns to trading volume. Remaining sectors could not reject the null hypothesis.

\section{SUMMARY AND IMPLICATIONS}

The study has examined the granger causality relationship between trading volume and stock returns for Nepalese stock market. In particular, the study used ADF and PP unit root tests to determine the time series properties of both trading volume and stock returns. For causality test, the study applied the Granger causality test models.

The results from the various unit root tests indicate that stock returns are level stationary but trading volume are not level stationary. The study use log difference trading volume for further analysis. The result from the standard Granger causality test provided a unidirectional Granger causality running from stock returns to trading volume but not vice versa. This study detected unidirectional causality from stock returns to trading volume as found by Heimstra and Jones(1994) in Dow Jones stock returns and New York stock exchange, Ciner (2002) in Tokyo commodity futures market and Mahajan and Singh (2009) in Indian stock market and Meshkin, Gargaz and Abbasi (2014) in Tehran stock exchange that is indicative of noise trading model of return-volume interaction in this market. The results presented in this study helps to increase our understanding regarding the relationship between trading volume and stock returns, particularly for the NEPSE. These findings also help to explain the behaviour of returns and a better understanding of market movement. It also indicated that any study of trading volume and returns is necessarily relating to information flow and possibly to identify a better proxy for information flow. From investment perspective, the relationship between stock returns and trading volume is of great importance to individuals who invest and trace 
a perspective as trading volume reflects information about market expectations and its relationship with price, having important implications on trading, speculation, forecasting and finally on hedging activities.

These results are useful for regulators, market participants, and the efficiency of the share market sector. The results are useful for regulators when they consider such measures as limits on price movements and positions. For market participants, the results are useful since they imply that volume can be used to predict prices, lending support to technical analysis. Finally, the results imply market inefficiency that may be due to the fact that traders may condition their prices on previous volumes.

The findings have a number of important implications for future research in this area. First, the results contribute to the empirical literature on Nepalese stock market by highlighting detectable Granger linear causalities. In addition, the findings of significant unidirectional Granger causality from trading volume to stock returns illustrate the importance of these predictor variables in the forecasting of stock prices.

\section{BIBLIOGRAPHY}

Abdullahi, S., Kouhy, R., \& Muhammad, Z. (2014). Trading volume and return relationship in the crude oil futures markets. Studies in Economics and Finance, 31(4), 426-438.

Andersen, T. G. (1996). Return volatility and trading volume: An information flow interpretation of stochastic volatility. Journal of Finance, 51(1), 169-204.

Attari, J. M., Rafiq, S. A., \& Awan, H. M. (2012). The dynamic relationship between stock volatility and trading volume. Asian Economic and Financial Review, 2(8), 1085-1097.

Campbell, J., Grossman, S., \& Wang, J. (1993). Trading volume and serial correlation in stock returns. Quarterly Journal of Economics, 108, 905-939.

Chen, G., Firth, M., \& Rui, O. (2001). The dynamic relation between stock returns, trading volume and volatility. The Financial Review, 38, 153-174.

Ciner, C. (2002). Information content of volume: An investigation of Tokyo commodity futures markets. Pacific Basin Financial Journal, 10, 201-215.

Clark, P. (1973). A subordinated stochastic process model with finite variance for speculative prices. Econometrica, 41, 135-155.

Conrad, J., Hameed, A., \& Niden, C. (1994). Volume and auto covariance in short horizon individual security returns. The Journal of Finance, 49(4), 305-1329.

Copeland, T. (1976). A model of assets trading under the assumption of sequential information arrival. Journal of Finance, 31, 1149-1168.

Darrat, A., Rahman, S., \& Zhong, M. (2003). Intraday trading volume and return volatility of the DJIA stock: A note. Journal of Banking and Finance, 27, 2035-2043.

Darwish, M. (2012). Testing the contemporaneous and causal relationship between trading volume and return in the Palestine exchange. International Journal of Economics and Finance, 4(4), 182-192. Retrieved from: http://dx.doi.org/10.5539/ijef.v4n4p182

Dickey, D., \& Fuller, W. (1981). Likelihood ratio statistics for autoregressive time series with unit root. Econometrica, 49, 057-1072.

Epps, T. W. (1975). Security price changes and transaction volumes: Theory and evidence. American Economic Review, 65, 586-597.

Epps, T., \& Epps, M. (1976). The stochastic dependence of security price changes and transaction volumes: Implications for mixture of distribution hypothesis. Econometrica, 44, 305-321.

Fama, E. (1965). The behavior of stock-market prices. The Journal of Business, 38(1), 34-105. G.C., S., \& Neupane, S. (2006). Stock market and economic development: A causality test. The 
Journal of Nepalese Business Studies, 3(1), 36-44.

Gallant, A., Rossi, P., \& Tauchen, G. (1992). Stock prices and volume. Review of Financial Studies, 5, 199-242.

Granger, C. (1969). Investigating causal relations by econometric models and cross-spectral methods. Econometrica, 37, 424-438.

Gwilym, Mc. M., \& Speight. (1999). The intraday relationship between volume and volatility in LIFFE future markets. Applied Financial Economics, 9(6), 593-604.

Halova, M. W. (2012). The Intraday Volatility-Volume Relationship in Oil and Gas Futures. Manuscript. Retrieved from: http://dx.doi.org/10.1080/096031099332041

Hatrick, K., So, M. K., Chung, S. W., \& Deng, R. (2011). Dynamic relationship among intraday realized volatility, volume and number of trades. Asia-Pacific Financial Markets, 18(3), 291317.

Hiemstra, C., \& Jones, J. (1994). Testing for linear and nonlinear granger causality in the stock price-volume relation. Journal of Finance, 49, 1693-1664.

Hussain, S. (2011). The intraday behaviour of bid-ask spreads, trading volume and return volatility: Evidence from DAX30. International Journal of Economics and Finance, 3(1), 23-34.

Jain, P., \& Joh, G. (1988). The dependence between hourly prices and trading volume. Journal of Financial and Quantitative Analysis, 23, 269-283.

James, C., \& Edmister, R. (1983). The relation between common stock returns trading activities and market value. Journal of Finance, 38, 1075-1086.

Johansen, S. (1988). Statistical analysis of co-integration vectors. Journal of Economic Dynamics and Control, 12, 231-254.

Kamath, R. (2008). Return distribution and the day-of-the-week effects in the stock exchange of Thailand. Journal of Economics and Finance, 22(2-3), 97-106.

Karpoff, J. (1987). The relation between price changes and trading volume: A survey. Journal of Financial and Quantitative Analysis, 22, 109-126.

Lamoureux, C., \& Lastrapes, W. (1994). Endogenous trading volume and momentum in stock return volatility. Journal of Business and Economic Statistics, 12(2), 253-260.

Lamourex, C., \& Lastrapes, W. (1990). Heteroskedasticity in stock return data: Volume Versus GARCH effects. The Journal of Finance, 45(1), 21-29.

LeBaron, B. (1992). Some relations between volatility and serial correlation in stock market returns. Journal of Business, 65, 199-219.

Luu, J., \& Martens, M. (2003). Testing the mixture-of-distributions hypothesis using "Realized" volatility. 23, 661-679.

Mahajan, S., \& Singh, B. (2008). An empirical analysis of stock price-volume relationship in Indian stock market. Vision, 12(3), 1-13.

Mahajan, S., \& Singh, B. (2009). The empirical investigation of relationship between return, volume, and volatility dynamics in Indian stock market. Eurasian Journal of Business and Economics, 2, 113-137.

Meshkin, S., Gargaz, M., \& Abbasi, E. (2014). Investigation of the relationship between trading volume, volatility and stock return in Tehran stock exchange. Journal of Applied Science and Agriculture, 9(9), 145-153.

Parkinson, M. (1980). The extreme value method for estimating the variance of the rate of return. Journal of Business, 53, 61-65.

Reddy, S. (1997). Efficiency of Indian stock markets: An empirical analysis of weak-form EMH of the BSE. UTI Indian Capital Market Conference, 91-115.

Samman, H., \& Al-Jafari, M. (2015). Trading volume and stock returns volatility: Evidence from industrial firms of Oman. Asian Social Science, 11(24), 139-146.

Sarwar, G. (2003). The Interrelation of price volatility and trading of currency options. The Journal of Futures Markets, 23, 681-700.

Stevenson, A., \& Bear, M. (1970). Commodity futures: Trends or random walks? The Journal of Finance, 25(1), 65-81.

Ying, C. (1966). Stock market prices and volumes of sales. Econometrica, 34, 676-685. 
24 I PYC Nepal Journal of Management, August 2016, Vol. IX, No. 1

\section{ANNEX 1 Descriptive statistic of variables}

The data for this table are collected and compiled from the listed at Nepal Stock Exchange Limited for the period 2064.01 to 2071.11(July 2007 to February 2015) with 92 months .The table contained monthly stock returns and trading volume at index level. The monthly trading volume is calculated by multiplying number of shares traded times closing share price. The monthly trading volume has been used for volume $\left(\mathrm{V}_{t}\right)$. The monthly stock returns are calculated by natural log of current closing stock index divided by lagged closing stock index, i.e. monthly stock returns $\left(R_{i}\right)-L N\left(\frac{h_{i}}{n_{-1}}\right)$. In the table, $\mathrm{N}$ represents number of observations and mean, median, maximum and minimum for average, maximum and minimum returns respectively for the period. SD stands for standard deviation of the returns. SK is a measure of skewness and KURT represents kurtosis. The Jarque-Bera (JB) test of normality is the test of the joint hypothesis that SK and KURT are 0 and 3 , respectively. In that case, the value of the JB statistic is expected to be zero. JB is defined as

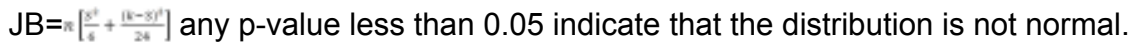

Panel I

$\begin{array}{ccccccccccc}\text { Var } & \text { Mean } & \text { Med } & \text { Max } & \text { Min } & \text { SD } & \text { SK } & \text { KURT } & \text { JB Stat. } & \text { Prob } & \text { N } \\ \mathrm{R}_{\mathrm{t}} & 0.0039 & 0.0171 & 1.3438 & -1.4224 & 0.3313 & -0.3949 & 13.8980 & 457.661 & (0.000) & 92 \\ \mathrm{~V}_{\mathrm{t}} & 2407.46 & 1511.62 & 15211.61 & 386.11 & 2602.151 & 2.4131 & 9.7233 & 262.565 & (0.000) & 92\end{array}$

Panel II

\begin{tabular}{|c|c|c|c|c|c|c|c|c|c|c|c|}
\hline Sector & Var & Mean & Med & Max & Min & SD & SK & KURT & JB Stat & Prob & $\mathbf{N}$ \\
\hline \multirow{2}{*}{ CB } & $\mathrm{R}_{\mathrm{t}}$ & 0.084 & 0.421 & 30.323 & -21.555 & 10.259 & 0.273 & 3.428 & 1.842 & $(0.398)$ & \multirow{2}{*}{92} \\
\hline & $V_{t}$ & 1654.896 & 929.805 & 21887.150 & 117.550 & 3069.450 & 5.093 & 31.319 & 3471.892 & $(0.000)$ & \\
\hline \multirow{2}{*}{ DB } & $\mathrm{R}_{\mathrm{t}}$ & 0.468 & -0.912 & 50.553 & -40.705 & 12.406 & 0.764 & 7.780 & 96.535 & $(0.000)$ & \multirow{2}{*}{92} \\
\hline & $V_{t}$ & 347.152 & 130.005 & 5753.390 & 33.350 & 788.790 & 5.476 & 34.882 & 4356.290 & $(0.000)$ & \\
\hline \multirow{2}{*}{ FIN } & $R_{t}$ & 0.150 & -1.198 & 39.745 & -26.007 & 8.091 & 1.287 & 9.611 & 192.908 & $(0.000)$ & \multirow{2}{*}{92} \\
\hline & $V_{t}$ & 147.701 & 87.260 & 1161.160 & 15.160 & 183.065 & 3.253 & 16.408 & 851.413 & $(0.000)$ & \\
\hline \multirow{2}{*}{ HP } & $R_{t}$ & 1.054 & -0.584 & 35.338 & -42.027 & 11.295 & -0.116 & 5.157 & 18.051 & $(0.000)$ & \multirow{2}{*}{92} \\
\hline & $v_{t}$ & 299.544 & 127.855 & 4749.640 & 14.470 & 602.499 & 5.149 & 35.161 & 4371.439 & $(0.000)$ & \\
\hline \multirow{2}{*}{ HTL } & $\mathrm{R}_{\mathrm{t}}$ & 2.316 & 0.504 & 39.832 & -13.684 & 7.723 & 2.685 & 13.269 & 503.619 & $(0.000)$ & \multirow{2}{*}{90} \\
\hline & $V_{t}$ & 46.005 & 3.560 & 756.320 & 0.010 & 120.231 & 4.116 & 21.514 & 1539.592 & $(0.000)$ & \\
\hline \multirow{2}{*}{ INS } & $\mathrm{R}_{\mathrm{t}}$ & 2.096 & 0.676 & 53.937 & -16.777 & 9.330 & 2.257 & 12.362 & 414.088 & $(0.000)$ & \multirow{2}{*}{92} \\
\hline & $V_{t}$ & 323.507 & 32.280 & 5575.400 & 2.750 & 833.549 & 4.579 & 26.173 & 2380.032 & $(0.000)$ & \\
\hline \multirow{2}{*}{ MFG } & $R_{t}$ & 1.694 & 0.657 & 42.775 & -33.860 & 8.487 & 0.882 & 14.717 & 491.425 & $(0.000)$ & \multirow{2}{*}{84} \\
\hline & $V_{t}$ & 105.644 & 3.800 & 5232.100 & 0.010 & 585.293 & 8.194 & 71.824 & 17518.680 & $(0.000)$ & \\
\hline \multirow{2}{*}{ OTR } & $\mathrm{R}_{\mathrm{t}}$ & -0.023 & 0.222 & 20.658 & -15.268 & 6.763 & 0.271 & 3.484 & 1.736 & $(0.420)$ & \multirow{2}{*}{79} \\
\hline & $V_{t}$ & 42.549 & 25.320 & 304.840 & 3.640 & 56.798 & 3.258 & 14.112 & 546.138 & $(0.000)$ & \\
\hline \multirow{2}{*}{ TRD } & $R_{t}$ & 0.264 & 0.000 & 43.977 & -16.369 & 7.142 & 2.648 & 18.815 & 961.945 & $(0.000)$ & \multirow{2}{*}{83} \\
\hline & $V_{t}$ & 2.317 & 1.590 & 11.660 & 0.010 & 2.323 & 1.392 & 5.018 & 40.897 & $(0.000)$ & \\
\hline
\end{tabular}




\section{Annex 2 Summary result of Unit root test}

This table reports the results of the $A D F$ test and PP test for unit roots. The lag length $(p)$ is chosen based on AIC. The empirical model; $\Delta Y_{t}=\mu+\delta Y_{t-1}+\sum_{i=1}^{m} \alpha_{j} \Delta Y_{t-i}+\gamma t+\varepsilon_{t}$ where $\Delta Y_{t}$ is the first difference of the time series variable and $i$ is the lag order of the autoregressive process. A constant $\mu$ and the coefficient on a time trend $\gamma$ are also incorporated in the model to account for the different possibilities of the unit root process. If $\mu=0$ and $\gamma=0$, it corresponds to a random walk model and if only $\gamma=0$, it equals to modeling a random walk with drift.

Panel /

\begin{tabular}{ccccccccc}
\hline \multirow{2}{*}{ Variables } & \multicolumn{3}{c}{ ADF Unit Root Test } & & \multicolumn{3}{c}{ PP Unit Root Test } \\
\cline { 2 - 3 } \cline { 7 - 8 } & None & Constant & $\begin{array}{c}\text { con.\& } \\
\text { trend }\end{array}$ & & None & Constant & con.\& trend \\
\hline \multirow{2}{*}{$\mathrm{R}_{\mathrm{t}}$} & -15.241 & -15.159 & -15.133 & & -15.577 & -15.492 & -16.111 \\
& $(0.000)$ & $(0.000)$ & $(0.000)$ & & $(0.000)$ & $(0.000)$ & $(0.000)$ \\
$\mathrm{V}_{\mathrm{t}}$ & -1.739 & -2.580 & -3.179 & & -1.493 & -2.288 & -2.956 \\
& $(0.078)$ & $(0.101)$ & $(0.095)$ & & $(0.126)$ & $(0.178)$ & $(0.150)$ \\
$\left.\mathrm{D}\left(\log \mathrm{V}_{\mathrm{t}}\right)\right)$ & -12.277 & -12.223 & -12.187 & & -14.215 & -14.402 & -15.014 \\
& $(0.000)$ & $(0.000)$ & $(0.000)$ & & $(0.000)$ & $(0.000)$ & $(0.000)$ \\
\hline
\end{tabular}

Panel /I

\begin{tabular}{|c|c|c|c|c|c|c|c|}
\hline \multirow[b]{2}{*}{ Sector } & \multirow[b]{2}{*}{ Variables } & \multicolumn{3}{|c|}{ ADF Unit Root Test } & \multicolumn{3}{|c|}{ PP Unit Root Test } \\
\hline & & None & Constant & $\begin{array}{l}\text { con.\& } \\
\text { trend }\end{array}$ & None & Constant & $\begin{array}{l}\text { con.\& } \\
\text { trend }\end{array}$ \\
\hline \multirow{6}{*}{$\mathrm{CB}$} & & -9.613 & -9.560 & -9.731 & -9.612 & -9.560 & -9.731 \\
\hline & $\mathrm{R}_{\mathrm{t}}$ & $(0.000)$ & $(0.000)$ & $(0.000)$ & $(0.000)$ & $(0.000)$ & $(0.000)$ \\
\hline & & 2.876 & 2.418 & 2.939 & -4.390 & -5.094 & -5.749 \\
\hline & $\left(v_{t}\right)$ & (0.999) & $(1.000)$ & $(1.000)$ & $(0.000)$ & $(0.000)$ & $(0.000)$ \\
\hline & & -9.401 & -9.373 & -8.625 & -12.692 & -12.633 & -13.374 \\
\hline & $D\left(\log \left(V_{t}\right)\right)$ & $(0.000)$ & $(0.000)$ & $(0.000)$ & $(0.000)$ & $(0.000)$ & $(0.000)$ \\
\hline \multirow{6}{*}{ DB } & & -8.493 & -8.456 & -6.405 & -8.489 & -8.453 & -8.462 \\
\hline & $\mathrm{R}_{\mathrm{t}}$ & $(0.000)$ & $(0.000)$ & $(0.000)$ & $(0.000)$ & $(0.000)$ & $(0.000)$ \\
\hline & & 1.254 & 1.830 & 2.369 & -3.958 & -4.455 & -4.937 \\
\hline & $\left(V_{t}\right)$ & $(0.946)$ & $(1.000)$ & $(1.000)$ & $(0.000)$ & $(0.001)$ & $(0.001)$ \\
\hline & & -9.512 & -9.496 & -9.581 & -11.143 & -12.156 & -19.137 \\
\hline & $D\left(\log \left(V_{t}\right)\right)$ & $(0.000)$ & $(0.000)$ & $(0.000)$ & $(0.000)$ & $(0.000)$ & $(0.000)$ \\
\hline \multirow{6}{*}{ FIN } & & -4.212 & -4.189 & -5.864 & -6.732 & -6.691 & -6.684 \\
\hline & $R_{t}$ & $(0.000)$ & $(0.001)$ & $(0.000)$ & $(0.000)$ & $(0.000)$ & $(0.000)$ \\
\hline & & 0.014 & -0.848 & -0.517 & -3.100 & -4.463 & -4.442 \\
\hline & $\left(V_{t}\right)$ & (0.685) & $(0.800)$ & $(0.981)$ & $(0.002)$ & $(0.001)$ & $(0.003)$ \\
\hline & & -9.371 & -9.322 & -9.285 & -13.443 & -13.361 & -13.483 \\
\hline & $\mathrm{D}\left(\log \left(\mathrm{V}_{\mathrm{t}}\right)\right)$ & $(0.000)$ & $(0.000)$ & $(0.000)$ & $(0.000)$ & $(0.000)$ & $(0.000)$ \\
\hline
\end{tabular}


26 I PYC Nepal Journal of Management, August 2016, Vol. IX, No. 1

\begin{tabular}{|c|c|c|c|c|c|c|c|}
\hline \multirow[b]{2}{*}{ Sector } & \multirow[b]{2}{*}{ Variables } & \multicolumn{3}{|c|}{ ADF Unit Root Test } & \multicolumn{3}{|c|}{ PP Unit Root Test } \\
\hline & & None & Constant & $\begin{array}{l}\text { con.\& } \\
\text { trend }\end{array}$ & None & Constant & $\begin{array}{l}\text { con.\& } \\
\text { trend }\end{array}$ \\
\hline \multirow{6}{*}{ HP } & & -10.547 & -10.540 & -10.732 & -10.553 & -10.548 & -10.806 \\
\hline & $R_{t}$ & $(0.000)$ & $(0.000)$ & $(0.000)$ & $(0.000)$ & $(0.000)$ & $(0.000)$ \\
\hline & & 1.151 & 0.572 & -0.897 & -5.900 & -6.945 & -7.993 \\
\hline & $\left(v_{t}\right)$ & $(0.935)$ & $(0.988)$ & $(0.951)$ & $(0.000)$ & $(0.000)$ & $(0.000)$ \\
\hline & $\mathrm{D}(\log (\mathrm{V}))$ & -8.591 & -8.549 & -8.504 & -28.330 & -27.710 & -37.056 \\
\hline & 管 & $(0.000)$ & $(0.000)$ & $(0.000)$ & $(0.000)$ & $(0.000)$ & $(0.000)$ \\
\hline \multirow{6}{*}{ HTL } & & -7.593 & -8.074 & -8.194 & -7.754 & -8.102 & -8.183 \\
\hline & $\mathrm{R}_{\mathrm{t}}$ & $(0.000)$ & $(0.000)$ & $(0.000)$ & $(0.000)$ & $(0.000)$ & $(0.000)$ \\
\hline & & 2.106 & 0.614 & -0.422 & -4.059 & -4.419 & -5.030 \\
\hline & $\left(v_{t}\right)$ & $(0.991)$ & $(0.989)$ & $(0.985)$ & $(0.000)$ & $(0.001)$ & $(0.000)$ \\
\hline & & -14.634 & -14.564 & -14.497 & -18.465 & -18.586 & -20.007 \\
\hline & $D\left(\log \left(v_{t}\right)\right)$ & $(0.000)$ & $(0.000)$ & $(0.000)$ & $(0.000)$ & $(0.000)$ & $(0.000)$ \\
\hline \multirow{6}{*}{ INS } & & -2.641 & -7.952 & -8.485 & -7.915 & -8.010 & -8.476 \\
\hline & $\mathrm{R}_{\mathrm{t}}$ & $(0.009)$ & $(0.000)$ & $(0.000)$ & $(0.000)$ & $(0.000)$ & $(0.000)$ \\
\hline & & 4.036 & 3.284 & 1.894 & -4.002 & -4.404 & -5.374 \\
\hline & $\left(v_{t}\right)$ & $(1.000)$ & $(1.000)$ & $(1.000)$ & $(0.000)$ & $(0.001)$ & $(0.000)$ \\
\hline & & -9.566 & -9.605 & -9.590 & -15.312 & -17.728 & -25.188 \\
\hline & $D\left(\log \left(v_{t}\right)\right)$ & $(0.000)$ & $(0.000)$ & $(0.000)$ & $(0.000)$ & $(0.000)$ & $(0.000)$ \\
\hline \multirow{6}{*}{ MFG } & & -8.229 & -8.919 & -8.945 & -10.228 & -14.953 & -24.447 \\
\hline & $R_{t}$ & $(0.000)$ & $(0.000)$ & $(0.000)$ & $(0.000)$ & $(0.000)$ & $(0.000)$ \\
\hline & & -8.679 & -8.907 & -9.165 & -8.679 & -8.907 & -9.165 \\
\hline & $\left(v_{t}\right)$ & $(0.000)$ & $(0.000)$ & $(0.000)$ & $(0.000)$ & $(0.000)$ & $(0.000)$ \\
\hline & & -9.863 & -9.829 & -9.751 & -37.535 & -47.008 & -48.715 \\
\hline & $D\left(\log \left(v_{t}\right)\right)$ & $(0.000)$ & $(0.000)$ & $(0.000)$ & $(0.000)$ & $(0.000)$ & $(0.000)$ \\
\hline \multirow{6}{*}{ OTR } & & -10.674 & -10.618 & -11.009 & -10.425 & -10.376 & -10.779 \\
\hline & $\mathrm{K}_{\mathrm{t}}$ & $(0.000)$ & $(0.000)$ & $(0.000)$ & $(0.000)$ & $(0.000)$ & $(0.000)$ \\
\hline & $(1)$ & -0.149 & -1.154 & -6.957 & -5.362 & -6.786 & -8.611 \\
\hline & $\left(v_{t}\right)$ & $(0.629)$ & $(0.690)$ & $(0.000)$ & $(0.000)$ & $(0.000)$ & $(0.000)$ \\
\hline & & -8.194 & -8.152 & -8.175 & -18.853 & -18.494 & -19.880 \\
\hline & $D\left(\log \left(v_{t}\right)\right)$ & $(0.000)$ & $(0.000)$ & $(0.000)$ & $(0.000)$ & $(0.000)$ & $(0.000)$ \\
\hline \multirow{6}{*}{ TRD } & & -9.164 & -9.116 & -9.132 & -9.266 & -9.239 & -9.388 \\
\hline & $\mathrm{R}_{\mathrm{t}}$ & $(0.000)$ & $(0.000)$ & $(0.000)$ & $(0.000)$ & $(0.000)$ & $(0.000)$ \\
\hline & $(\gamma)$ & -2.078 & -5.697 & -5.965 & -3.386 & -5.663 & -5.948 \\
\hline & $\left(v_{t}\right)$ & $(0.037)$ & $(0.000)$ & $(0.000)$ & $(0.001)$ & $(0.000)$ & $(0.000)$ \\
\hline & $\mathrm{D}(\mathrm{log}$ & -9.965 & -9.902 & -9.834 & -32.099 & -34.628 & -35.204 \\
\hline & (ivg & $(0.000)$ & $(0.000)$ & $(0.000)$ & $(0.000)$ & $(0.000)$ & $(0.000)$ \\
\hline
\end{tabular}




\section{Annex 3 Summary result of Johansen's Co-integration test}

This table reports the results of the Johansen's Co-integration test. There are two statistics to process co-integration. (A).Trace test; the empirical model for trace test is where, T is sample size, is estimate of characteristic root. If test rejects that means variables exist at least $r+1$ long term co-integrated relationship. and (b). Maximum eigenvalue test; The empirical model for maximum eigenvalue test is . The Johansen's cointegration test statistic of the sample firms for the period of 2064.4 to 2071.11(July 2007 to February 2015). P-values are in the parentheses

\section{Panel/}

\begin{tabular}{ccccccc}
\hline Eigenvalue & Trace value & H0 & H1 & Max-Eigen statistic & H0 & H1 \\
\hline 0.3992 & $80.4560^{*}$ & $r=0$ & $r \geq 1$ & $44.8336^{*}$ & $r=0$ & $r=1$ \\
0.3329 & $35.6264^{*}$ & $r \leq 1$ & $r \geq 2$ & $35.6264^{*}$ & $r \leq 1$ & $r=2$ \\
\hline
\end{tabular}

Note: * indicates significance at less than $1 \%$ level. Trace test and Max-Eigen test indicate 1 co-integrating equation(s) at $1 \%$ level.

Panel /l

\begin{tabular}{ccccccccc}
\hline Sector & Eigen value & Trace value & H0 & H1 & Max-Eigen & H0 & H1 & Eqn.\# \\
\hline \multirow{2}{*}{ CB } & 0.562 & 94.98 & $r=0$ & $r \geq 1$ & 72.647 & $r=0$ & $r=1$ & 2 \\
& 0.224 & 22.33 & $r \leq 1$ & $r \geq 2$ & 22.333 & $r \leq 1$ & $r=2$ & \\
DB & 0.442 & 79.92 & $r=0$ & $r \geq 1$ & 51.409 & $r=0$ & $r=1$ & 2 \\
& 0.277 & 28.51 & $r \leq 1$ & $r \geq 2$ & 28.513 & $r \leq 1$ & $r=2$ & \\
FIN & 0.443 & 68.39 & $r=0$ & $r \geq 1$ & 51.533 & $r=0$ & $r=1$ & \\
& 0.174 & 16.85 & $r \leq 1$ & $r \geq 2$ & 16.852 & $r \leq 1$ & $r=2$ & 2 \\
HP & 0.485 & 80.49 & $r=0$ & $r \geq 1$ & 58.356 & $r=0$ & $r=1$ & \\
& 0.222 & 22.14 & $r \leq 1$ & $r \geq 2$ & 22.139 & $r \leq 1$ & $r=2$ & \\
HTL & 0.344 & 53.43 & $r=0$ & $r \geq 1$ & 36.321 & $r=0$ & $r=1$ & 2 \\
& 0.18 & 17.1 & $r \leq 1$ & $r \geq 2$ & 17.104 & $r \leq 1$ & $r=2$ & \\
INS & 0.461 & 69.83 & $r=0$ & $r \geq 1$ & 54.332 & $r=0$ & $r=1$ & 2 \\
& 0.161 & 15.5 & $r \leq 1$ & $r \geq 2$ & 15.496 & $r \leq 1$ & $r=2$ & \\
MFG & 0.466 & 94.33 & $r=0$ & $r \geq 1$ & 50.129 & $r=0$ & $r=1$ & 2 \\
& 0.424 & 44.2 & $r \leq 1$ & $r \geq 2$ & 44.2 & $r \leq 1$ & $r=2$ & 2 \\
\multirow{2}{*}{ OTR } & 0.524 & 74.51 & $r=0$ & $r \geq 1$ & 55.622 & $r=0$ & $r=1$ & 2 \\
& 0.223 & 18.89 & $r \leq 1$ & $r \geq 2$ & 18.892 & $r \leq 1$ & $r=2$ & \\
\multirow{2}{*}{ TRD } & 0.488 & 82.43 & $r=0$ & $r \geq 1$ & 52.811 & $r=0$ & $r=1$ & 2 \\
& 0.313 & 29.62 & $r \leq 1$ & $r \geq 2$ & 29.616 & $r \leq 1$ & $r=2$ & \\
\hline
\end{tabular}


28 I PYC Nepal Journal of Management, August 2016, Vol. IX, No. 1

\section{Annex 4 Summary Statistics of Granger-causality test}

The variable volume $\left(V_{t}\right)$ is the log difference of trading volume in month $t$, Stock returns, $R_{t}$, is the monthly stock returns. F-statistics of the Granger-causality test are shown for the period of 2064.4 to 2071.11(July 2007 to February 2015) P-values are in the parentheses

Panel/

\begin{tabular}{lcc}
\hline \multicolumn{1}{c}{ Null Hypothesis } & F-Statistic & (P-Value) \\
\hline $\mathrm{V}_{\mathrm{t}}$ does not Granger Cause $\mathrm{R}_{\mathrm{t}}$ & 1.0151 & $(0.4148)$ \\
$\mathrm{R}_{\mathrm{t}}$ does not Granger Cause $\mathrm{V}_{\mathrm{t}}$ & $2.22631^{*}$ & $(0.0602)$ \\
\hline
\end{tabular}

Note: ${ }^{* \star} 1 \%$ or less, ${ }^{* *}$ up to $5 \%,{ }^{*}$ up to $10 \%$ level significant.

Panel /I

\begin{tabular}{|c|c|c|c|}
\hline Sector & Null Hypothesis & F Statistic & P Value \\
\hline \multirow{2}{*}{ CB } & $V_{t}$ does not Granger Cause $R_{t}$ & $4.350^{* *}$ & $(0.016)$ \\
\hline & $R_{t}$ does not Granger Cause $V_{t}$ & $2.658^{*}$ & $(0.076)$ \\
\hline \multirow{2}{*}{ DB } & $V_{t}$ does not Granger Cause RET & 0.185 & $(0.831)$ \\
\hline & $R_{t}$ does not Granger Cause $V_{t}$ & 0.082 & $(0.921)$ \\
\hline \multirow{2}{*}{ FIN } & $V_{t}$ does not Granger Cause $R_{t}$ & $2.814^{*}$ & $(0.066)$ \\
\hline & $R_{t}$ does not Granger Cause $V_{t}$ & 0.256 & $(0.775)$ \\
\hline \multirow{2}{*}{$\mathrm{HP}$} & $V_{t}$ does not Granger Cause $R_{t}$ & 1.848 & $(0.164)$ \\
\hline & $R_{t}$ does not Granger Cause $V_{t}$ & 1.809 & $(0.170)$ \\
\hline \multirow{2}{*}{ HTL } & $V_{t}$ does not Granger Cause $R_{t}$ & 0.367 & $(0.694)$ \\
\hline & $V_{t}$ does not Granger Cause $V_{t}$ & 0.275 & $(0.760)$ \\
\hline \multirow{2}{*}{ INS } & $V_{t}$ does not Granger Cause $R_{t}$ & 1.328 & $(0.270)$ \\
\hline & $R_{t}$ does not Granger Cause $V_{t}$ & 0.088 & $(0.916)$ \\
\hline \multirow{2}{*}{ MFG } & $V_{t}$ does not Granger Cause $R_{t}$ & 0.759 & $(0.472)$ \\
\hline & $R_{t}$ does not Granger Cause $V_{t}$ & $3.412^{* *}$ & $(0.038)$ \\
\hline \multirow{2}{*}{ OTR } & $V_{t}$ does not Granger Cause $R_{t}$ & 0.874 & $(0.422)$ \\
\hline & $R_{t}$ does not Granger Cause $V_{t}$ & 0.893 & $(0.414)$ \\
\hline \multirow{2}{*}{ TRD } & $V_{t}$ does not Granger Cause Vt & 2.235 & $(0.114)$ \\
\hline & $R_{t}$ does not Granger Cause $V_{t}$ & 0.054 & $(0.947)$ \\
\hline
\end{tabular}

